\title{
Stalin's scientific deputy addresses dissident meeting
}

THE inclusion of a symposium on scientific research in the Venice Biennale on culture has been described as an "act of considerable courage". Since the general theme of the 1977 Biennale was "cultural dissidence" it was hardly surprising that the round table on scientific freedom should include many who have shown considerable physical and moral courage in the defence of academic liberty. Voronel, Turchin, Plyushch, Dediu, Zhores Medvedev, the Papiashvilis, the Chudovskii brothers - the list of speakers reads almost like a role of honour of the dissident movement in science. Moral courage of no less an order, however, was shown by Dr Arnost Kolman, who, to an audience of active campaigners for scientific liberty, delivered a paper that, under the unassuming title of "The Adventure of Cybernetics in the USSR" described his part in Stalin's campaign to destroy free scientific progress, and replace it by a special partyorientated science.

Dr Kolman, at 85 , is a living link with Lenin and the early days of Soviet power. His personal philosophy still remains Marxism, which he sees as having become under Stalin "the obedient servant-girl of political power". His picture of his destruction of science during those years is a horrifying one, since, he explained, it was carried out not by cynical careerists, but by people acting in good faith, but incompetent in the field in question.

Thus he, himself, trained in maths and physics, campaigned during those years against the prevailing philosophy, in defence of relativity, quantum physics, and mathematical logic. In life sciences, however, and particularly in genetics, he was fully prepared to accept the party dogma which pronounced genetics a pseudo-science. He

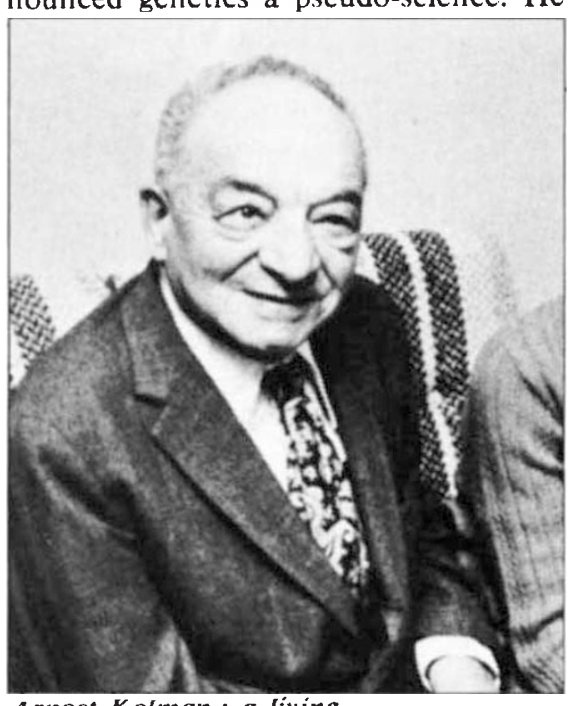

Arnost Kolman : a living

link with the early days of Soviet power described how the editorial board of the philosophical magazine, Under the Banner of Marxism, of which he was a member, were given a mere three months to familiarise themselves with the theory and problems of heredityand then to take up the battle against "mendelo-morganism", championing the "innovatory ideas" of Lysenko.

Kolman's paper was not only absorbing-as the mea culpa of a notable figure has always been fascinating from the days of Augustine of Hippo onwards-it also set the tone for the whole symposium by stressing the danger inherent on state interference in science. Zhores Medvedev gave a most lucid account of Soviet science policy during the last 60 years, several papers dealt with more recent events in Czechoslovakia (Frantisek Janouch, L. Durovic, and O. Poupa) and in Romania (Mihai Dediu). Kolman's revelations showed, however, that such interference need not necessarily be effected by bureaucrats or party apparatchiki, but by persons who genuinely believe that in doing so they are serving their country and the cause of scientific progress.

Against this background the more theoretical papers took on a significance transcending the current situation in the USSR and Eastern Europe. John Ziman's masterly exposition of the ethical principles underlined the concept of scientific liberty. Giorgio Bert on "Medical Science as an Ideology", Mark Popovskii on "Controlled Science", and Valentin Turchin's enquiry into the correlation between scientific training and involvement in human rights, all raised fundamental problems of the moral responsibility of scientists everywhere.

Likewise, in the special session on the political misuse of psychiatry, Dr Sidney Bloch noted that the revelation during the last few years of Soviet malpractices had caused many psyohiatrists throughout the world to reassess their personal ethical standards.

A number of speakers, in particular Giacomo Morpurgo, stressed the need for rapid and accurate dissemination of information of scientists subject to restriction and deprivation of academic liberty. The work of Amnesty International did not go unnoticed; but it was stressed that Amnesty campaigns only for those actually in prison. Owing to the rapid advance of science, exclusion from professional activity for more than a few months may produce irreversible academic "death". Hence the intervention of the world scientific community at the initial stages of academic restriction is a matter of considerable importance. A prime example of what can be achieved was the worldwide outcry against the campaign to expel Sakharov from the Soviet Academy of Sciences in 1973. Reports of specific efforts were received from Jeremy Stone (Federation of American Scientists), Tania Mathon (Solidarity Committee of French Scientists) and Goran Borg (Swedish Committee for the Freedom of Science).

Repeatedly throughout the symposium it was stressed that, although the theme of this particular meeting was repression and dissent in Europe, the problem of scientific liberty is indivisible and transcends all national frontiers. It is an integral part of the world-wide problem of human rights: if the cases of scientists command particular attention, it is because in this post-atomic age, the outcome of state misuse of science and technology can threaten the future of the entire world. The ethical responsibilities of scientists to their profession and to their colleagues are accordingly proportionally great.

Vera Rich

\section{Sakharov warns of subtle pressure}

The Soviet physicist Andrei Sakharov sent a personal message to last wcek's Venice Biennale. The following is an extract from his message:

"Liberty of opinion and exchange of information are of great importance throughout the world. . . The new climate of international relations, called detente, has led to even more complex and varied links and communications, hence not only have the possibilities of positive influences been increased, but also the danger of the diffusion of more negative characteristics. This has increased mutual responsibility. . . 1 consider the initiative of the Biennale to be very important, dedicated as it is to the problem of dissidents and non-official creativity in the socialist countries. I myself belong to this scientific sector in which the ideological pressure of the state is nowadays not expressed cntirely explicitly. ... The epoque of the ideological struggle against the theory of relativity, quantum mechanics and cybernetics - the most shameful page in Soviet science fortunately belongs to the past.

(Now) perhaps the most important thing is the humiliating position of the intelligentsia in the whole country, which is shown particularly in the inadmissible misery of the two most wide-spread intellectual professionsdoctors and teachers-and in the total subjection of the intelligentsia to bureaucratic party control". 